\title{
Mainstreaming in Kingdom of Saudi Arabia: Obstacles Facing Learning Disabilities Resource Room
}

\author{
Suhail Mahmoud Al-Zoubi \\ Department of Special Education, Najran University, KSA \\ E-mail: suhailalzoubi@yahoo.com OR smalzoubi@nu.edu.sa \\ Majdoleen Sultan Bani Abdel Rahman \\ Department of Special Education, Najran University, KSA \\ E-mail: majdoleen77@yahoo.com OR msmuhammed@nu.edu.sa
}

Received: December 5, 2015 Accepted: January 6, 2015 Published: February 1, 2016

doi:10.5296/jse.v6i1.8800

URL: http://dx.doi.org/10.5296/jse.v6i1.8800

\begin{abstract}
The aim of this study was to identify the obstacles facing learning disabilities resource room (LDRR). The sample of the study consisted of 42 teachers working in learning disabilities resource room (LDRR) at Najran in the Kingdom of Saudi Arabia (KSA). A questionnaire was developed and distributed to the sample of the study. The results indicated that there were obstacles facing LDRR related to learning disabilities teacher, collaboration of others, and facilities and equipment.
\end{abstract}

Keywords: facilities and equipment, general educators, learning disabilities teacher, mainstreaming, obstacles, resource room, school headmaster 


\section{Introduction}

Special education includes a set of the educational placements for students with special needs (Hallahan, Kauffman \& Pullen, 2012). Resource room is one of these placements that used for students with learning disabilities(SLD), (Al-Khateeb \& Hadidi, 2010). It is a classroom attached to the regular school contains individualized educational program (IEP), for SLD who are facing problems in academic skills (Mohammed \& Ahmad, 2013). The role of resource room is highlighted when the general curriculum and general educators are unable to solve academic problems for SLD(Raymond, 2012). Thus, SLD enrolled in resource room according to a special schedule and they spend $21-60 \%$ of their school day in resource room (Lerner \& Johns, 2012).

Resource room is classified into categorical, cross-categorical, non-categorical, specific-skills, and itinerant (Bender, 2008). While the categorical resource room or LDRR is the most commonly types used by Ministry of Education in the KSA(Al-Zoubi \& Bani Abdel Rahman. 2012). The KSA is seeking through LDRR to keep up with contemporary global trends in mainstreaming SLD at least restrictive environment (LRE). The LRE comes in response to Individuals with Disabilities Education Act (IDEA). The LRE allows for SLD to receive their instruction in the regular classroom (Sawalha \& Turki, 2013).

LDRR need to be qualified with teachers, facilities and equipment in addition a collaboration of school administration, general educators, and parents of SLD. The present study highlights the role of LDRR at Najran, KSA through identifying obstacles that may reduce the effectiveness of LDRR.

Educational systems began focused on quality programs in preparation and training teachers in order to acquire the skills and knowledge(Akalin \& Sucuoglu, 2015).Therefore, working in LDRR requires from learning disabilities teachers several roles such as planning, teaching and assessing of SLD (Al-Zoubi, 2011). It also requires from them to collaborate with multidisciplinary team (Mercer, Mercer \& Pullen, 2011). learning disabilities teachers must possess competencies and personal skills (Al-Zoubi, Bani Abdel Rahman \& Ismail, 2010; Al-Zoubi, Bani Abdel Rahman, 2011; Ismail, Al-Zoubi, Bani Abdel Rahman \& Al-Shabatat, 2009). The preparation of special education teachers conducted through pre-service training programs (PSTP) and in-service training programs (ISTP) (Theeb, Muhaidat \& Al-Zboon, 2014).

The PSTP is the responsibility of higher education institutions. The main goal of PSTP of special education teachers is to enable them to teach and practice efficiently (Vuran, Ergenekon \& Unlu, 2014). While, PSTP must focuses on collaborative with professionals and families of students with special needs (Brownell, Ross, Colon \& McCallum, 2005).

ISTP is one of responsibilities of the Ministry of Education (Amr, 2011). ISTP aims at improving teaching skills and potentials of teachers (Kazemi \& Ashrafi, 2014). It provides learning disabilities teachers with knowledge and performance competencies (Al-Zoubi, 2011). Thus, the process of acquiring these competencies contribute to meet the needs of students with special needs (Cooper, Kurtts, Baber \& Vallecorsa, , 2008). The effective 
special education teachers are showing a tendency towards the establishment of collaboration with school staff (Gazo, Qaryouti \& Sartawi, 2004). The preparation of IEP requires from special education teachers to build a positive relationships with school administration, general educators and parents (deBettencourt \& Howards, 2015). In this regard, IDEA confirmed the clarify of the contribution methods and support provided by school administration and general educators in IEP(deBettencourt \& Howard, 2015).

The IDEA demand special education teachers as consultants for general educators. According to IDEA, special and general educators must demonstrate a spirit of collaboration (Winn \& Blanton, 2005). The collaboration between them is also part of requirements No Child Left Behind Act (NCLB), (Itkonen, 2007). Based on IDEA and NCLB, the job description of special education teacher has changed (Hall, 2007). In other words, special education teachers need to know the ways of collaboration with general educators (Garderen, Stormont \& Goel, 2010).

Special education teachers need to obtain support from school headmaster (bays, 2004). This collaboration will increase the effectiveness of teachers in inclusion education (Hines, 2008). The school headmaster could be advanced in mainstreaming education settings by building bridges of collaboration between special and general educators(Abbott, 2006). In this regard, Radiac-Sestic et al. (2013) pointed out that teamwork contributes to assist school headmaster to develop of strategies based on support, education and organization that will enhance collaboration between special and general educators in inclusive education programs.

General educators face difficulties in finding harmony between normal and disabled students (Hodgson, McCulloch \& Fox, 2011). Therefore, they cannot encounter the diverse needs of students with special needs without getting support from special education teachers (Blask, 2011; Stockall, 2014). The Council for Exceptional Children (CEC) recommended to demonstrate collaboration between special and general educators (CEC, 2015). This collaboration provides opportunities for them to share their skills (Kritikos \& Bimaum, 2003; Tannock, 2009; Blask, 2011). Krüger and Yorke (2010) emphasized the positive impacts of collaborative co-teaching strategy on the performance and interactions of general education teachers. Hence, the collaboration between special and general educators is the key to success of mainstreaming and inclusive education of students with special needs(Dağlı \& Öznacar, 2015).

Special education teachers needs support and participation from parents of SLD (Al-Khateeb, 2001). This participation has become one of the criteria that determine the effectiveness of the programs offered for students with special needs (Sawalmah, Abu Zaid \& Bini Melhem, 2012; Cole, 2007). The relationships between teachers and parents of SLD must depend on mutual respect (Gross, 2011).

Teaching aids and computers are considered the main keys for success of LDRR (Al-Shebaneah, 2009). LDRR must be in compatible with international quality standards through including educational equipment (Ali, 2009). LDRR should contain special sections to develop reading, writing, and mathematics skills (Youssefi, 2014). The Technology-Related Assistance Act (P.L. 100-407) confirmed the effectiveness of use 
technology to reduce cognitive deficits among SLD (Day \& Edwards, 1996). Pillay and Terlizzi (2009) recommend to contain of IEP on computer-based instruction, teaching aids and occupational therapy programs.

\section{Method}

\subsection{Research Design}

The descriptive analytical method was used to determine the obstacles facing LDRR.

\subsection{Participants}

The population of the study consisted of 63 teachers working at LDRR in Najran, KSA. While, the sample consisted of 42 learning disabilities teachers who answered the questionnaire.

\subsection{Instrument}

A questionnaire was used. The first draft of the questionnaire contained (31) items reviewed by six faculty members from the Department of Special Education at Najran University, KSA. The final draft consisted of (24) items, distributed into three domains related to learning disabilities teacher (9) items, collaboration of others (8) items, and facilities and equipment of LDRR (7) items. In addition, the Cronbach's Alpha formula was used to test the reliability of the questionnaire. The reliability of each domain is as follows: learning disabilities teacher $(\mathrm{r}=0.83)$, collaboration of others $(\mathrm{r}=0.77)$, and facilities and equipment $(\mathrm{r}=0.81)$. The Five Point Likert Scale was used (strongly agree (5), mildly agree (4), neutral (3), mildly disagree (2), and strongly disagree (1)). In order to analyze the results, the mean classified for three levels (low, moderate, and high). Low $(\mathrm{M}=1-2.33)$, moderate $(\mathrm{M}=2.34-3.67)$, and high $(\mathrm{M}=3.68-5)$.

\section{Results}

\subsection{Results related to the first question}

What are the obstacles facing LDRR?. For this question, means and standard deviations calculated as shown in Table 1

Table 1. Means and standard deviations according to domains of obstacles

\begin{tabular}{lcccc}
\hline Domain & $\mathrm{N}$ & $\mathrm{M}$ & $\mathrm{SD}$ & Level \\
\hline Learning Disabilities Teacher & 42 & 2.85 & .211 & Moderate \\
Collaboration of Others & 42 & 2.87 & .263 & Moderate \\
Facilities and Equipment & 42 & 2.90 & .305 & Moderate \\
\hline
\end{tabular}

Table 1 shows that all domains of the questionnaire got a moderate level of obstacles by perspective of learning disabilities teachers. However, in order to identify the most obstacles 
facing LDRR teachers, Table 2 presents the domain items of learning disabilities teachers.

Table 2. Means and standard deviations of domain items of learning disabilities teacher

\begin{tabular}{|c|c|c|c|c|}
\hline $\mathrm{N}$ & Items & M & $\mathrm{SD}$ & Level \\
\hline 1 & $\begin{array}{l}\text { Weakness of pre-service academic preparation } \\
\text { programs }\end{array}$ & 4.52 & .594 & High \\
\hline 2 & $\begin{array}{l}\text { Weakness of in-service professional training } \\
\text { programs }\end{array}$ & 4.40 & .543 & High \\
\hline 3 & $\begin{array}{l}\text { Weakness of preparation, implementation and } \\
\text { evaluation of IEP }\end{array}$ & 4.21 & .682 & High \\
\hline 4 & Low of application teaching strategies for SLD & 2.23 & 617 & Low \\
\hline 5 & Weakness of knowledge of behavior modification & 2.21 & .564 & Low \\
\hline 6 & Unwillingness to teaching in LDRR & 2.09 & .849 & Low \\
\hline 7 & Slow academic progress among SLD & 2.07 & .462 & Low \\
\hline 8 & Low of motivation among teachers & 2.02 & .643 & Low \\
\hline 9 & Lack of material and moral incentives & 1.95 & .622 & Low \\
\hline
\end{tabular}

Table 2 shows the means of the items of learning disabilities teacher ranged between $(4.52-$ 1.95). The items of $(1,2$, and 3$)$ were classified as high-level obstacles, while the items of (4, $5,6,7,8$ and 9) were classified as a low obstacles. Table 3 presents results of domain items of collaboration of others. 
Table 3. Means and standard deviations of domain items of collaboration of others

\begin{tabular}{|c|c|c|c|c|}
\hline $\mathrm{N}$ & Items & M & SD & Level \\
\hline 10 & $\begin{array}{l}\text { Low of school administration participation in } \\
\text { LDRR }\end{array}$ & 4.40 & .664 & High \\
\hline 11 & $\begin{array}{l}\text { Low of general education teachers participation in } \\
\text { LDRR }\end{array}$ & 4.38 & .660 & High \\
\hline 12 & Low of parents of SLD participation in LDRR & 4.19 & .890 & High \\
\hline 13 & $\begin{array}{l}\text { Low parents beliefs towards effectiveness of } \\
\text { LDRR }\end{array}$ & 2.14 & .683 & Low \\
\hline 14 & $\begin{array}{l}\text { Weakness of parents participation in teachers- } \\
\text { parents councils }\end{array}$ & 2.09 & .576 & Low \\
\hline 15 & $\begin{array}{l}\text { Negative school administration \& teachers } \\
\text { perception towards SLD }\end{array}$ & 2.04 & .882 & Low \\
\hline 16 & Lack of LDRR for funding & 1.95 & .763 & Low \\
\hline 17 & Negative perception of society towards LDRR & 1.78 & .645 & Low \\
\hline
\end{tabular}

Table 3 shows the means of the items of collaboration of others ranged between $(4.40-1.78)$. The items of $(10,11$, and 12) were classified as high-level of obstacles, whereas the items of $(13,14,15,16$ and 17) were classified as low obstacles. Table 4 presents results of domain items of facilities and equipment. 
Table 4. Means and standard deviations of domain items of facilities and equipment

\begin{tabular}{clccc}
\hline $\mathrm{N}$ & Items & $\mathrm{M}$ & $\mathrm{SD}$ & Level \\
\hline 18 & Lack of standardized scales in the field of LD & 4.40 & .828 & High \\
19 & Lack of LDRR for a guide & 4.19 & .993 & High \\
20 & Lack of LDRR for computer and Internet & 3.38 & 1.058 & Moderate \\
21 & Lack of LDRR for teaching aids & 2.26 & .496 & Low \\
22 & Lack of LDRR for special room & 2.11 & .550 & Low \\
23 & Lack of LDRR for library & 2.02 & .643 & Low \\
& $\quad$ Lack of LDRR for security and public safety & 1.92 & .600 & Low \\
\hline
\end{tabular}

Table 4 demonstrates the means of the items of facilities and equipment domain ranged between $(4.40-1.92)$. The items of (18 and 19) were classified as high-level of obstacles, whereas item (20) was classified as moderate obstacles. Furthermore, the items of $(21,22,23$ and 24) were classified as low obstacles.

\subsection{Results related to the second question}

Are there any statistically significant differences in obstacles facing LDRR due to gender?. For this question, means, standard deviations and t-test were calculated as shown in table 5.

Table 5. Means, standard deviations and t-test according to gender

\begin{tabular}{lcccccc}
\hline Domain & Gender & $\mathrm{N}$ & $\mathrm{M}$ & $\mathrm{SD}$ & $\mathrm{t}$ & $\mathrm{P}$ \\
\hline LDRR Teacher & Male & 24 & 2.87 & .195 & .371 & .713 \\
& Female & 18 & 2.84 & .235 & & \\
Collaboration of Others & Male & 24 & 2.88 & .264 & .146 & .884 \\
& Female & 18 & 2.86 & .269 & & \\
Facilities and Equipment & Male & 24 & 2.86 & .293 & -.937 & .354 \\
& Female & 18 & 2.95 & .321 & & \\
\hline
\end{tabular}

Table 5 illustrates that there were no statistical significant differences in obstacles facing LDRR that can be attributed to gender. 


\subsection{Results related to the third question}

Are there any statistically significant differences facing LDRR due to teaching experience?. For this question, means, standard deviations and t-test were calculated as shown in table 6 .

Table 6. Means, standard deviations and t-test according to teaching experience

\begin{tabular}{lcccccc}
\hline Domain & Teaching Experience & $\mathrm{N}$ & $\mathrm{M}$ & $\mathrm{SD}$ & $\mathrm{t}$ & $\mathrm{P}$ \\
\hline LDRR Teacher & $1-5$ & 25 & 2.85 & .186 & -.237 & .814 \\
& $6-10$ & 17 & 2.86 & .249 & & \\
Collaboration of Others & $1-5$ & 25 & 2.89 & .251 & .592 & .557 \\
& $6-10$ & 17 & 2.84 & .284 & & \\
Facilities and Equipment & $1-5$ & 25 & 2.89 & .338 & -.253 & .802 \\
& $6-10$ & 17 & 2.91 & .257 & & \\
\hline
\end{tabular}

Table 6 illustrates that there were no statistical significant differences facing LDRR that can be attributed to the teaching experience.

\section{Discussion}

In general, the results showed that the obstacles facing LDRR were moderate. The following is discussion the items that are classified as high or moderate obstacles.

\subsection{Obstacles facing learning disabilities teacher}

Results confirmed the weakness in PSTP, INSTP, and preparation of IEP. Based on these results, we must reconsider of PSTP and ISTP of learning disabilities teachers in KSA. Special Education Departments at Saudi universities concentrate on theoretical courses more than practical courses. The practicum is only course which students enrolled it during the last semester. Consequently, the Special Education Departments at Saudi universities should distribute the practicum to all semesters, as well as organizing a scheduled visits in each semester to LDRR.

The quality of special education programs at Saudi universities lack key performance indicators and benchmarks (Al-Zoubi \& Bani Abdel Rahman, 2013). In the international level, the preparation of special education teacher needs to be paid more attention (Renitta, Jerry \& Ann, 2004). However, Mason-Williams (2015) affirmed that the preparation special education teacher face challenges since more than 30 years ago. For this reason, the preparation of special education teachers has received considerable attention (deBettencourt, 2004). The quality of educational services for children with special needs depends on the abilities, skills, and qualifications of special education teachers. Therefore, the majority of special education teachers have problems in working with students with special needs (Bouck, 2005).

Al-Hiary, Almakanin and Tabbal (2015) demonstrated that there are problems facing learning 
disabilities students in PSTP related to practicum. Theeb et al.(2014) stressed that the special education students have the ability to acquire skills of preparation IEP and collaborating with families. On the other hand, PSTP should include programs that are related to planning and teaching methods (Cook, 2007). Loiacono and Allen (2008) recommended the training of special education students on behavior modification. Murray and Curran (2008) recommended training courses at universities to provide opportunities for special education students to meet with parents of students with special needs. Mamlin (2012) affirmed the benefit of practicum in PSTP is to improve teacher's ability to teach students with special needs. Moreover, Hanline (2010) confirmed that the practicum has a positive impact on skills and knowledge of special education teachers. Additionally, Al Khateeb and Hadidi (2009) emphasized the impact of PSTP on performance of special education teachers.

Results showed a weakness of ISTP. These results could be justified due to a lack of workshops held by the Directorate of Special Education at Najran in KSA. There is a weakness in coordination between the Directorate and Department of Special Education at Najran University. In this regard, Payne (2005) revealed that the weaknesses of preparation of special education teachers which is attributable to lack of coordination between universities and Ministry of Education. Whereas, Veale, Dobbins, and Kurtts (2013) concentrated on concerted efforts between Ministry of Education and Higher Education Institutions. Bakhsh (2009) concluded that ISTP of special education teachers suffering from lack of coordination between special education institutions. Therefore, The level of job satisfaction among teachers of special education programs is still controversial among researchers, the teachers need to be trained on methods of dealing with changes in the curriculum, administrative duties, and ways to deal with students with special needs (Strydom, Nortjé, Beukes, Esterhuyse \& Westhuizen, 2012). Thus, special education teachers need workshops in assessment, behavior modification, assistive technology, and collaboration with others (Al-Ahmary, 2010; Giles, 2009; Nelson, 2009; Taylor, 2008; Loiacono \& Allen, 2008).

The researchers in this study believed that the weaknesses in preparation of learning disabilities teachers in PSTP and ISTP will lead to weaknesses in preparation, implementation and evaluation of IEP. The IEP is core work of learning disabilities teacher in LDRR. Thus, the preparation of IEP requires a number of steps including determine the present level of academic achievement and functional performance (PLAAFP). The IDEA requires that IEP includes PLAAFP, long-term and short-term goals (deBettencourt \& Howard, 2015). Therefore, LDRR at Najran lacks of multi-disciplinary team and this lack will reflect negatively in identification of SLD. Several studies confirmed the existence of obstacles and challenges facing of learning disabilities teachers and LDRR related to determine PLAAFP, diagnosis of SLD, and preparation of IEP(Abduljabbar, 2003; Al-Khasawneh, 2013; Al-Natour, Alkhmara \& Al-Smadi, 2008;Homidi, 2013; Nasser, 2006).

\subsection{Obstacles facing collaboration of others}

The results emphasized that there were obstacles that decrease the effectiveness of LDRR in the domain of collaboration of others. These challenges are related to the lack of participation of the school administration, general educators, and parents of SLD in LDRR. 
The success of IEP depends on the contribution of school headmaster by creating social interactions, participation and collective decision-making among the team work in IEP (Al-Khateeb, 2013). The school headmaster contributes in creating collaboration between learning disabilities teacher and general educators (Al-Ayed, 2010; Fankhauser, 2010). While, the school headmaster must have a set of skills related to knowledge of characteristics of students with special needs and problems facing learning disabilities teacher. Crockett (2002) emphasized that the school headmaster performed many tasks in the mainstreaming setting such as planning programs and application of laws and legislation related to the students with special needs. The possession of the school headmaster for these tasks helped to increases motivation among teachers. In contrast, the lack of support by the school administration is one of causes of burnout among special education teachers (Plash \& Piotrowski, 2006). The researchers of this study affirmed that the enrollment of the school headmaster in workshops may contribute his/her participation in LDRR. Boscardin (2004) and Sawalhah (2014) recommended enrollment of the school headmaster in workshops related to issues and developments in special education.

The results showed low participation of general educators in LDRR. This can be attributed to lack of enough time for teachers to demonstrate collaboration with learning disabilities teacher. Carter, Prater, Jackson, and Marchant (2009) pointed out that the lack of enough time is one of obstacles to collaborate between special and general educators. Whereas, Skrtic, Harris and Shriner (2005) attributed causes of this lack to pull-out of students with special needs from regular classroom to special education settings. Therefore, to achieve this collaboration effectively, it should be provided special education teachers with the necessary skills and competencies (Cramer, 2006). Yildiz (2015) recommended to enroll teachers who work in the inclusive classrooms in in-service training programs in order to provide them with effective teaching skills.

The adaptation of curricula for students with special needs is considered the most obstacles that restrict of collaboration between special and general educators (Winn \& Blanton,2005). While, Rabani and Ghaferi (2009) stressed that the teaching methods of students with special needs are obstacles facing general education teachers in mainstreaming setting. However, Ngcobo and Muthukrishna (2011) showed a lack of support and collaboration that provides for teacher who is teaching in inclusive education classes from their colleagues. As a result, Carter et al. (2009) believed that the effective collaboration requires for administrative support. Therefore, the realization of collaboration between two parties will reflect positively on the academic and behavior aspects of students with special needs(Garderen et al., 2012). As a result, special education teachers can help general education teachers to implement strategies effectively for students with special needs in regular classrooms (Murawski \& Hughes, 2009; Nguyen, 2012). This requires from special education teachers to provide general educators with self-understanding, effective teaching, and knowledge of policies (Eccleston,2010).

The results also showed a weakness in participation of parents of SLD in LDRR. This can be attributed to the lack of educational awareness among parents of SLD towards the importance of communication with learning disabilities teacher and to culture and trends among parents 
in Najran which are still negative towards LDRR. In this regard, Somaily, Al-Zoubi, and Bani Abdel Rahman (2012) stressed a lack of information among parents of SLD towards LDRR which may be due to weakness of communication between parents and learning disabilities teachers and negative social customs and traditions in Najran towards LDRR. Al Khateeb and Hadidi (2009) indicated that learning disabilities teacher expressed their dissatisfaction with low involvement of parents of SLD in preparation of educational programs. In contrast, Qassas and Al-Jmeha (2014) emphasized avoiding involvement of parents of SLD in educational programs and in the extracurricular activities. AlMalki (2011) justified the lack of knowledge of parents of SLD toward mainstreaming to lack access to books, journals, and scientific websites related learning disabilities. Zouaydi (2007) pointed out that negative of social attitudes toward special education programs. Whereas, Al-Jaddou (2015) emphasized a weakness of interpersonal relationships between parents of students with special needs and special education teachers. Al-Makanin (2012) attribute this weakness to inability of special education teachers to build collaboration with parents of SLD. To overcome this weakness, Sawalmah et al. (2012) recommended that special education teachers should use modern technology such as Mobil, SMS, e-mail and social networking to communicate with parents of SLD.

\subsection{Obstacles of facilities and equipment}

The results emphasized that there were obstacles that decrease the effectiveness of LDRR. These obstacles related to lack of standardized scales, lack of guide, and weakness of computer and Internet in LDRR. The standardized scales in the KSA need a national efforts between Ministry of Education and Ministry of Higher Education in building partnership. In contrast, the informal tests are only used by learning disabilities teachers in the KSA. Furthermore, Bateman and Herr (2003) confirmed that good writing to PLAAFP must be specific, objective and measurable. While, the formulation of long-term and short-term goals based on the scales which are used to measure the PLAAFP( deBettencourt \& Howard, 2015). Furthermore, Bani Abdel Rahman and Al-Zoubi (2014) showed that learning disabilities teachers faced problems related in the lack of appropriate scales for assessing SLD.

The results of the study indicated that there is no guide for LDRR. This can be explained that the education mainstreaming in the KSA is still recent.Thus, the Ministry of Education in KSA must prepare a guide includes vision, mission, goals, objectives of LDRR and determine the policies, legislation and roles of the school administration, general educators, parents, students, and learning disabilities teacher. The results also indicated a weakness in equipping LDRR with computers and the Internet. This can be attributed to a lack of interest of the school administration and the Directorate of Special Education at Najran towards providing LDRR with these equipment. The use of technology in educational process helps students with special needs to improve their capabilities (Alnahdi, 2014; Mull \& Sitlington, 2003). The assistive technology is useful in teaching reading and writing skills for SLD (Skylar, 2007; Flanagan, Bouck, \& Richardson, 2013).

LDRR suffer from lack of teaching aids, furniture, and communication technology (Ali, 2011). Bataineh and Alshehri (2010) emphasized the lack of LDRR in the KSA for teaching 
aids and computer. Engelbrecht, Nel, Nel and Tlale (2015) Indicated a number of obstacles facing inclusive education programs which related to lack of resources and trends of teachers. On the other hand, Al-Johani and Al-Zarea (2014) explained the obstacles facing learning disabilities teachers in using auditory aids in teaching reading skills for SLD. On the other hand, the lack of resources and support systems have a negative impact on job satisfaction of special education teachers(Castro, Kelly \& Shih, 2010). Al Khateeb and Hadidi (2009) and Swanson (2008) stressed that the educational services in LDRR are still low quality. Moreover, the school facilities and equipment have not arranged since the beginning of the schools establishment to meet the needs of students with special needs (Rabani \& Ghaferi, 2009).

\section{Acknowledgments}

The researchers would like to extend their gratitude to the Deanship of Scientific Research at Najran University for funding this research project, under the grant number (NU/SHED14/010), and special thanks go to Dr. Ismail Rushwan from the Department of English in Najran University for his contribution in editing this manuscript.

\section{References}

Abbott, L. ( 2007). Northern Ireland special educational needs coordinators creating inclusive environments: an epic struggle. European Journal of Special Needs Education, 22(4), 391-407. http://dx.doi.org/10.1080/08856250701650003

Abduljabbar, A. ( 2003). The training programs necessary for special education teachers. Message of Education and Psychology, 21(2), 139-180.

Akalin, S., \& Sucuoglu, B. (2015). Effects of classroom management intervention based on teacher training and performance feedback on outcomes of teacher-student dyads in inclusive classrooms. Educational Sciences: Theory \& Practice, 15(3), 739-758. http://dx.doi.org/10.12738/estp.2015.3.2543

Al Khateeb, J., \& Hadidi, M. (2009). Teachers' and Mothers' satisfaction with resource room programs in Jordan. The Journal of the International Association of Special Education, 10(1),56-59.

Al-Ahmary, S. (2010). The training needs for learning disabilities teachers (Unpublished master thesis). King Saud University, Riyadh, Saudi Arabia.

Al-Ayed, W (2010). Level of support provided by school administration for resource room teachers. Journal of Taif University,1(1),85-117.

Al-Hiary, G., Almakanin. H., \& Tabbal, S. (2015). Problems faced by preservice special education teachers in Jordan. International Education Studies, 8(2), 128-141. http://dx.doi.org/10.5539/ies.v8n2p128

Ali, Z. (2011). Proposed model for the contents of learning disabilities resource rooms. Arab Journal of Educational Technology, 5, 153-179. 
Ali, Z. (2009). Quality standards of learning disabilities resource rooms in mainstream schools. Arab Journal of Educational Technology, 1, 168-199.

Al-Jaddou, E. (2015). Sources of job stress among special education teachers in Amman. Educational Sciences, 42, 361-393.

Al-Johani, S., \& Al-Zarea, N. (2014). Obstacles of using educational methods in teaching reading by teachers of learning disabilities students. International Interdisciplinary Journal of Education, 3(10), 98-122.

Al-Khasawneh, M. (2013).The effectiveness of educational services provided to students with learning disabilities in the resource room. Journal of Al-Quds Open University for Research \& Studies, 31, 51-76.

Al-Khateeb, A. (2013). Case study in special education. Irbid, Jordan: Modern Books.

Al-Khateeb, J. (2001). Parents of children with disabilities: Support and training strategies. Riyadh, Saudi Arabia: Academy of Special Education.

Al-Khateeb, J., \& Hadidi, M. (2010). Introduction to special education. Amman, Jordan: Dar AlFiker.

Al-Makanin H 2012. The effectiveness of the resource room services as perceived by schools principals. An-Najah University Journal for Research, 26(7), 1679-1698.

AlMalki, H. (2011). Inclusion of students with learning disabilities in elementary mainstreaming schools in Saudi Arabia: The viewpoint of parents (Unpublished master thesis). University of Southampton, Southampton, United Kingdom.

Alnahdi, G. (2014). Assistive technology in special education and the universal design for learning. Turkish Online Journal of Educational Technology, 13(2), 18-23.

Al-Natour, M., Alkhamra, H., \& Al-Smadi,.Y. (2008). Assessment of learning disabled students in Jordan. International Journal of Special Education, 23(2), 68-75.

Al-Shebaneah, Z. (2009). Children with learning disabilities in the resource room. Journal of Educational Development, 8, 66-67.

Al-Zoubi, S. (2011). A training program module: A practical guide for teachers of learning disabilities. Germany: Lambert Academic Publishing.

Al-Zoubi, S., \& Bani Abdel Rahman, M.(2011). The effects of a training program in improving instructional competencies for special education teachers in Jordan. Educational Research, 2(3),1021-1030.

Al-Zoubi, S., \& Bani Abdel Rahman, M.(2012). The effect of resource room on improving reading and arithmetic skills for learners with learning disabilities. The International Journal of Scientific Research in Education, 5(4), 269-277. 
Al-Zoubi, S., \& Bani Abdel Rahman, M.(2013). An evaluation of special education program in Saudi universities according to national standards. International Journal of Asian Social Science, 3(8), 1694-1703.

Al-Zoubi, S., Bani Abdel Rahman, M., \& Ismail, H. (2010). The effect of in-service training program in improving performance competencies for learning disabilities resource room teachers in Jordan. Educators Digest, 10(1), 4-11.

Amr, M. (2011). Teacher education for inclusive education in the Arab world: The case of Jordan. Prospects, 41, 399-413. http://dx.doi.org/10.1007/s11125-011-9203-9

Bakhsh, A. (2009). The reality of in-service training programs for special education teachers in Saudi Arabia. Educational Journal, 23, 125-171.

Bani Abdel Rahman, M., \& Al-Zoubi, S. (2014). The problems faced by teachers of Pioneer Centers for talented and gifted students. The Arab Journal of Talent development, 5(9), 166-186.

Bataineh, O., \& Alshehri. K. (2010). Reality of resource rooms from the perspective of learning disabilities teachers. Psychological and Educational Studies, 3(5),2-38.

Bateman, B., \& Herr, C. (2003). Writing measurable IEP goals and objectives. Verona, WI: Attainment.

Bays, D. (2004). Science in the schoolhouse: The critical role of the school leader. Journal of Learning Disabilities, 37(3), 256-261. http://dx.doi.org/10.1177/00222194040370031101

Bender, W. (2008). Learning disabilities: characteristics, Identification, and Teaching Strategies. Boston: Allyn \& Bacon.

Blask, F.(2011). Collaboration between general education teachers and related service providers. ERIC (ED 518582).

Boscardin, M. (2004). Transforming administration to support science in the schoolhouse for students with disabilities. Journal of Learning Disabilities, 37(3), 262-269. http://dx.doi.org/10.1177/00222194040370031201

Bouck, E. (2005). Secondary special educators: Perspectives of preservice preparation and satisfaction. Teacher Education and Special Education, 28(2), 125-139. http://dx.doi.org/10.1177/088840640502800206

Brownell, M., Ross, D., Colon, E., \& McCallum, C. (2005). Critical features of special education teacher preparation: A comparison with general teacher education. The Journal of Special Education, 38(4), 242-252.http://dx.doi.org/10.1177/00224669050380040601

Carter, N., Prater, M., Jackson, A., \& Marchant, M. (2009). Educators' perceptions of collaborative planning processes for students with disabilities. Preventing School Failure, 54(1), 60-70. http://dx.doi.org/10.3200/PSFL.54.1.60-70 
Castro, A., Kelly, J., \& Shih, M. (2010). Resilience strategies for new teachers in high-need areas. Teaching and Teacher Education, 26(3), 622-629. http://dx.doi.org/10.1016/j.tate.2009.09.010

Cole, B. (2007). Mothers, gender, and inclusion in the context of home-school relations. Support for learning, 22(4), 165-173. http://dx.doi.org/10.1111/j.1467-9604.2007.00467.x

Cook, L. (2007). When in Rome: Influences on special education student-teacher's teaching. International Journal of Special Education, 22(3), 118-130.

Cooper, J., Kurtts, S., Baber , C., \& Vallecorsa, A. (2008). A model for examining teacher preparation curricula for inclusion. Teacher Education Quarterly, 35(4), 155-176.

Council for Exceptional Children.(2015). CEC initial level special educator preparation standards. Available at http://www.cec.sped.org.

Cramer, S.(2006). The special educator's guide to collaboration: Improving relationships with co-teachers, teams, and families. Thousand Oaks, CA: Corwin Press.

Crockett, J. (2002). Special education's role in preparing responsive leaders for inclusive schools. Remedial and Special Education, 23(3), 157-168. http://dx.doi.org/10.1177/07419325020230030401

Dağl1, G., \& Öznacar, B. (2015). An evaluation on mainstreaming practices of primary schools according to the views of school administrators, teachers, and parents. Educational Sciences: Theory \& Practice, 15(5), 1317-1332. http://dx.doi.org/10.12738/estp.2015.5.2823

Day, S., \& Edwards, B. (1996). Assistive technology for postsecondary students with learning disabilities. Journal of learning disabilities, 29(5), 486-492. http://dx.doi.org/10.1177/002221949602900503

deBettencourt, L. (2004). Critical issues in training special education teachers. Exceptionality, 12(4),193-194. http://dx.doi.org/10.1207/s15327035ex1204_1

deBettencourt, L., \& Howard, L. (2015). The effective special education teacher: A practical guide for success. Illinois: Waveland Press.

Eccleston, S. (2010). Successful collaboration: Four essential traits of effective special education specialists. The Journal of International Association of Special Education, 11(1), 41-47.

Engelbrecht, P., Nel, M., Nel, N., \& Tlale, D. (2015). Enacting understanding of inclusion in complex contexts: classroom practices of South African teachers. South African Journal of Education, 35(3),1-10. http://dx.doi.org/10.15700/saje.v35n3a1074

Flanagan, C., Bouck, E., \& Richardson, J. (2013). Middle school special education teachers' perceptions and use of assistive technology in literacy instruction. Assistive Technology: The Official Journal of RESNA, 25(1), 24-30. http://dx.doi.org/10.1080/10400435.2012.682697 
Garderen, D., Stormont, M., \& Goel, N. (2012). Collaboration between general and special educators and student outcomes: a need for more research. Psychology in the Schools, 49(5),483-497. http://dx.doi.org/10.1002/pits.21610

Gazo, I., Qaryouti, I., \& Sartawi, A. (2004). Teaching skills of special education teachers in the United Arab Emirates. Paper presented at Teacher Preparation Conference, July 21-22, Egypt.

Giles, E. (2009). A phenomenon logical study of paraprofessionals perceptions of training and efficacy. (Unpublished doctoral dissertation), University of Phoenix, Phoenix, United State.

Gross, C. (2011). Parenting a child with learning disabilities: A viewpoint for teachers from a teacher and parent. Issues in Teacher Education, 20(1), 85-93.

Hadidi, M. (2003). Problems faced by resource room teachers in Jordan. The Arab Journal of Special Education, 2, 1-40.

Hall, S. (2007). NCLB and IDEA: Optimizing success for students with disabilities. Perspectives on Language and Literacy,33(1),35-38.

Hallahan, D., Kauffman, J., \& Pullen, P. (2012). Exceptional Learners: An introduction to special education. New Jersey: Person Education.

Hanline, M. (2010). Preservice teachers' perception of field experiences in inclusive preschool setting: Implications for personnel preparation. Teacher Education and Special Education, 33(4), 335-351. http://dx.doi.org/10.1177/0888406409360144

Hines, J. (2008). Making collaboration work in inclusive high school classrooms: Recommendations for principals. Intervention in School and Clinic, 43(5), 277-282. http://dx.doi.org/10.1177/1053451208314492

Hodgson, M., McCulloch, H., \& Fox, K. (2011). The experiences of people with severe and enduring mental illness engaged in a physical activity program integrated into the mental health service. Mental Health and Physical Activity, 4(1), 23-29. http://dx.doi.org/10.1016/j.mhpa.2011.01.002

Homidi, M. (2013). The degree of implementation of the individualized educational plan in autism programs. International Interdisciplinary Journal of Education, 2(12), 117-1135.

Ismail, H., Al-Zoubi, S., Bani Abdel Rahman, M., \& Al-Shabatat, A. (2009). Competency based teacher education (CBTE): A training module for improving knowledge competencies for resource room teachers in Jordan. European Journal of Social Sciences, 10(2), 166-178.

Itkonen, T. (2007). PL 94-142: policy, evolution, and landscape shift. Issues in Teacher Education, 16(2), 7-18.

Kazemi, A., \& Ashrafi, M. (2014). In-service training programs for Iranian EFL teachers revisited. International Journal of Asian Social Science,4(10),1062-1076. 
Kritikos, E., \& Birnbaum, B. (2003). General education and special education teachers' beliefs regarding collaboration. Learning Disabilities: A Multidisciplinary Journal, 12(3), 93-100.

Krüger, D., \& Yorke, C. (2010). Collaborative co-teaching of numeracy and literacy as a key to inclusion in an independent school. South African Journal of Education, 30(2), 293-306.

Lerner, J., \& Johns, B. (2012). Learning disabilities and related mild disabilities: Characteristics, teaching strategies and new directions (12th ed). Boston: Houghton Mifflin.

Loiacono, V., \& Allen, B. (2008). Are special education teachers prepared to teach the increasing number of students diagnosed with autism?. International Journal of Special Education, 23(2),120-127.

Mamlin, N. (2012). Preparing effective special education teachers. New York: Guilford Press.

Mason-Williams, L. (2015). Unequal opportunities: A profile of the distribution of special education teachers. Exceptional Children, 81(2), 247-262. http://dx.doi.org/10.1177/0014402914551737

Mercer, C., Mercer, A., \& Pullen, P. (2011). Teaching students with learning problems. Upper Saddle River, NJ: Pearson.

Mohammed, A., \& Ahmad, A. (2013). Job description for resource room teacher. Journal of Special Education and Rehabilitation, 1(1),1-12.

Murawski, W., \& Hughes, C. (2009). Response to intervention, collaboration, and co-teaching: A logical combination for successful systematic change. Preventing School Failure, 53(4), 267-277. http://dx.doi.org/10.1016/j.mhpa.2011.01.002

Murray, M., \& Curran, E. (2008). Learning together with parents of children with disabilities: Bringing parent-professional partnership education to a new level. Teacher Education and Special Education, 31(1), 59-63. http://dx.doi.org/10.1177/088840640803100106

Nelson, L. (2009). Creating quality special educators: An analysis of professional development of teachers of students with disabilities(Unpublished doctoral dissertation), Capella University, Minneapolis, United States.

Ngcobo, J., \& Muthukrishna, N. (2011). The geographies of inclusion of students with disabilities in an ordinary school. South African Journal of Education, 31(3), 357-368.

Nguyen, H. (2012).General education and special education teachers collaborate to support English language learners with learning disabilities. Issues in Teacher Education, 21(1),127-152.

Payne, R. (2005). Special education teacher shortage: barriers or lack of preparation?. International Journal of Special Education, 20(1), 88-91. 
Pillay, J., \& Terlizzi, M. (2009). A case study of a learner's transition from mainstream schooling to a school for learners with special educational needs (LSEN): lessons for mainstream education. South African Journal of Education, 29(4), 491-509.

Plash, S., \& Piotrowski, C. (2006). Retention issues: A study of the Alabama special education teachers. Education,127(1),125.

Qassas, K., \& Al-Jmeha, K. (2014). Level of participation parents of students with normal, learning disabilities, and intellectual disabilities in school educational process. Journal of Special Education and Rehabilitation, 1(4), 245-270.

Rabani, A., \& Ghaferi, M. (2009). Obstacles to mainstream students with special needs at general education schools in Oman. Ain Shams University Journal for Education, 33, 217-250.

Radiac-Sestic, M., Radovanovic, V., Milanovic-Dobrota, B., Slavkovic, S., \& Langovic-Milicvic, A. (2013). General and special education teachers' relations within teamwork in inclusive education: socio-demographic characteristics. South African Journal of Education, 33(3), 1-15. http://dx.doi.org/10.15700/201503070733

Raymond, E. (2012). Learners with mild disabilities. New Jersey: Pearson Education.

Renitta, G., Jerry, A., \& Anne, W. (2004). A training program for minority educators in special education and educational leadership. College Student Journal, 38, 1-15.

Sawalhah, A. (2014). Attitudes of public and private school headmasters' towards learning disabilities resource room program. Islamic University Journal for Educational \& Psychological Studies, 22(3), 155-179.

Sawalhah, A., \& Turki, J. (2013). The reality of learning disabilities resource rooms in public schools. International Interdisciplinary Journal of Education, 2(8),803-824.

Sawalmah, M., Abu Zaid, H., \& Bini Melhem, A. (2012). Forms of communication between special education teachers and families of children with special needs. Journal of Educational Sciences, 4, 290-311.

Skrtic, T., Harris, K., \& Shriner, J. (2005). Special education policy and practice: accountability, instruction, and social challenges. Denver, CO: Love Publishing.

Skylar, A. (2007). Using assistive technology to include low-performing students in peer tutoring: A little help from Mini-M. Journal of Special Education Technology, 22(1), 53-57.

Somaily, H., Al-Zoubi, S., \& Bani Abdel Rahman, M. (2012). Parents of students with learning disabilities attitudes towards resource room. International Interdisciplinary Journal of Education, 1(1), 1-5.

Stockall, N. (2014). When an aide really becomes an aid providing professional development for special education para professionals. Teaching Exceptional Children, 46(6), 197-205. http://dx.doi.org/10.1177/0040059914537202 


\section{Macrothink}

Journal of Studies in Education

ISSN 2162-6952

2016, Vol. 6, No. 1

Strydom, L., Nortjé, N., Beukes, R., Esterhuyse, K., \& Westhuizen, J. (2012). Job satisfaction amongst teachers at special needs schools. South African Journal of Education, 32(3), 255-266.

Swanson, E. (2008). Observing reading instruction for students with learning disabilities: A synthesis. Learning Disability Quarterly, 31(3),115-133. http://dx.doi.org/10.2307/25474643

Tannock, M. (2009). Tangible and intangible elements of collaborative teaching. Intervention and School and Clinic, 44(3), 173-178. http://dx.doi.org/10.1177/1053451208318682

Taylor, C. (2008). Identifying training needs of educational paraprofessionals (Unpublished doctoral dissertation), University of Oregon, Eugene, United States.

Theeb, R., Muhaidat, M., \& Al-Zboon, E. (2014). Professional competencies among pre-service teachers in special education from their perspectives. Education, 135(1), 133-143.

Veale, N., Dobbins, N., \& Kurtts, S. (2013). Career changers in special education: A collaborative direction in teacher preparation for school systems and institutions of Higher Education. Issues in Teacher Education, 22(2), 107-116.

Vuran, S., Ergenekon, Y., \& Unlu, E. (2014). Training process cycles for special education teachers and university supervisors: A Turkish context. Educational Sciences: Theory \& Practice, 14(1), 282-295. http://dx.doi.org/10.12738/estp.2014.1.1563

Winn, J., \& Blanton, L. (2005). The call for collaboration in teacher education. Focus on Exceptional Children, 38(2), 1-10.

Yildiz, N.(2015). Teacher and student behaviors in inclusive classrooms. Educational Sciences: Theory \& Practice, 15(1), 177-184. http://dx.doi.org/10.12738/estp.2015.1.2155

Youssefi, H. (2014). Enrichment of learning disabilities resources room according to multiple intelligence theory. Journal of Social Studies, 7(5), 143-164.

Zouaydi, M. (2007). Sources of stress and burnout among special education teachers. Journal of Educational \& Psychological Sciences, 23(2), 189-219. 